Asen Balikei on the development of basic socio-economic units in two Eskimo communities (Pp. $x+114$. Ottawa: Queen's Printer, 1964. 1.50 dollars). The author deals with the Arviligjaurmiut hunters of Pelly Bay and the Puvirniturmiut trappers of East Hudson Bay, and considers that the cultural changes among the Eskimos described are essentially changes in socio-economic organization.

\section{Uganda Museum, Kampala}

The Report of the Trustees of the Uganda Museum for 1962 and 1963 records a period in which there have been numerous ehanges of personnel both among trustees and staff (Pp. 29. Kampala: Uganda Museum, 1964). It has also been a time of great advance in every sphere of the Museum's activities. The primary task has been to collect traditional material before it is too late, and to this end a body of informed collectors, asked to fill specific gaps in the collections, has been organized throughout Uganda. The impact of independence in 1962 gave a great impetus to pride in Uganda's past, and preservation is now seen to be a matter of urgency. The Kebu Association in Arua, for example, sent a large number of specimens to fill an almost complete gap in the collections. A large historical exhibition, The Nile Quest, was shown in 1962 as a contribution to the Nile Centenary Festival.

\section{Museum of Applied Arts and Sciences, Sydney}

IN a modern and attractive format, the annual report of the Museum of Applied Arts and Seiences, Sydnoy, for the yoar ended December 31, 1963, records a total of more than 206,000 visitors, which is the highest figure reached within the eighty-three years of the Museum's existence (Pp. 28. Sydney : Museum of Applied Arts and Sciences, 1964). This result is due in no small measure to the high standard of recent exhibits, the intensified advertising programme and the increasing attention directed to the comfort and convenience of visitors. A major alteration during the period was the modernizing of the Museum's main entrance, thus relieving congestion at the front door and also creating a pleasing initial impact on visitors. The Planetarium and the 'Transparent Plastic Woman' continue to be very popular, and a major acquisition was the complete notebooks and papers of Lawrence Hargrave, Australia's aeronautical pioneer.

\section{New Reference Tools for Librarians}

New $R$ ?ference Tools for Librarians, compiled and edited by Hans Zell, contains some 2,000 entries of reference books, bibliographies and other publications on librarianship published in 1962-63 (Pp. v +232. Oxford: Robert Maxwell and Co., Ltd.; Long Island City, N.Y.: Maxwell International Inc., 1964. Gratis). It is intended to supplement standard reference works on the subject and does not include year books and annuals, annual reviews of progress or membership lists of learned societies and professional bodies. The emphasis is on British and American material and the scope is interpreted liberally to include material likely to be of service to librarians, and is not limited to material concerned with librarianship in the strict sense of the word. Entries are arranged under the Universal Decimal Classification.

The first supplement to New Reference Tools for Librarians, issued in March 1964, lists a further 600 new and forthcoming reference books, bibliographies and publications on librarianship, published in 1963-64, now including publishers' names. 'The second supplement includes a further 550 titles published in 1964, as well as some titles which appeared too late in 1964 for inclusion in previous catalogues. The emphasis is again on British and American publications (No. 1. Pp. 62. No. 2. Pp. 56. Oxford: Robert Maxwell and Co., Ltd.; Long Island City, N.Y. : Maxwell International Inc., 1964).

\section{Science Citation Index}

A BOoKLET issued by the Institute for Scientific Information is intended to assist the scientist or librarian to use effectively the Science Citation Index for searching the literature (Effective Use of the Science Citation Index: a Programmed Text. Pp. 52, Philadelphia: Institute for Scientific Information, 1964). A general description of the Index is followed by explanations of its construction; the abbreviations of titles, authors' names and references which are used, and the characteristic features of the system, are demonstrated.

\section{Papermaking Research}

THe British Paper and Board Industry Research Association at Kenley, Surrey, issues a quarterly journal called What We Are Doing. One section is confidential to members, but most of the remainder deals, usually in a general way, with the activities of the Association and contains book reviews and abstracts of scientific papers. Occasionally, for good measure, more detailed accounts of certain research activities of the Association are also released, the guiding principle being the extent to which they are of academic interest as distinct from technical importance. This is a wise policy, since it enables the outside world to assess the quality of some of the work being carried out by the Association. The June 1964 issue contains a typical example of this nature, dealing with the obviously important subject of the mechanism of rupture of paper under tension. An attempt is being made, and with some success, to correlate thin places in the paper with the path taken by the fracture propagated when a strip of paper breaks under tension. In the first example, the light transmitted by the paper through very small areas (approximately $0 \cdot 23 \mathrm{~mm}^{2}$ ) was used to track the potential weak spots (that is, thin spots) in the paper. Afterwards $\beta$-radiography was used to determine the corresponding weights per unit area, an obviously more exact method of measuring a weak spot than from the thickness. A computer was then used to formulate the possible rupture paths, the input being obtained directly from the automatic scanning of the $\beta$-radiographs. The latest results are a striking justification of this method of forecasting the rupture propagation, and they have also demonstrated the overwhelming influence of abnormalities in the structure of the edge of the paper in initiating rupture. This work should eventually lead to a more exact understanding of the mechanism of fracture of non. homogeneous materials.

\section{A New Source of Petroleum}

AFTER a quarter of a century's search for oil in the sheikhdom of Abu Dhabi, on the Trucial coast of Arabia, aptly described as "a place of sand and sky and wide rolling horizons", pioneer efforts have been rewarded in the discovery of a new source of crude oil and development of a commercial field at Abu Dhabi, inland at a place called Murban, some miles from the sea. There is an offshore oilfield, about fifty miles out to sea, off the Abu DhabiJebel Dhanna coast, which has been in production for two years or more, but the proving of the Murban oil area has been quite a different story. It is most uninviting territory, at least on surface, both from human and com. mercial points of view. " 26,000 square miles of rolling sand dunes which imperceptibly merge into the wastes of Arabia's 'Empty Quarter' ... noon temperatures of about 120 degrees Fahrenheit coupled with high humidity ... sandstorms, shortage of water ... difficulty of keeping food fresh and free from dust ..." - these are the conditions under which the geologists, geophysicists and engineers had to work during many unrewarding years. Actually, the first well in the Murban area was drilled ten years ago, to $12,500 \mathrm{ft}$; ; it yielded some oil and gas, but had to be abandoned for technical reasons; by unfortunate chance this well was located only about five miles north of the 